\title{
Chemical Induced Liver Injury: Types, Mechanisms and Biomarkers
}

\author{
Richa Sachan ${ }^{1}$, Rajbala Singh ${ }^{2}$ \\ ${ }^{1}$ Sungkyunkwan University, South Korea \\ ${ }^{2}$ kamboj Institute of pharmacy, Saharanpur, Uttarpradesh
}

\section{ABSTRACT}

Liver is a primary organ involved in biotransformation of foods and drugs. Liver diseases are a major worldwide problem; Hepatic disorders are mainly caused by toxic chemicals, e.g. - alcohol, carbon tetra chloride, anticancer agent, analgesic, anti-inflammatory drugs, anti-tuberculosis agent and heavy metals. Various risk factors for liver damage include age, gender, alcoholism, nutrition and genetic polymorphisms of cytochrome $\mathrm{P}_{450}$ have also been considered. The present review enumerate various hepatic diseases, risk factors and chemicals induced hepatic injury via different mechanical pathway as well as numerous biochemical changes viz. serum biomarkers, proteomics biomarkers, genomic biomarkers, metabolic biomarkers and micro RNA. This review could be immensely useful for researchers especially for pharmacologists, toxicologist working on hepatotoxicity and drug research organization.

Keywords: Liver; Biotransformation; Risk Factors.

\section{Introduction}

Liver, the largest organ of the human body located between the absorptive surface of gastrointestinal tract offer wide range of functions including protein synthesis, detoxification and production of biochemicals necessary for digestion ${ }^{[1]}$. It is central target of the toxicity of drug, xenobiotic and oxidative stress because of an important role in metabolism and relationship to the gastrointestinal tract. The frequent cause of hepatic injury is drug but it also depends upon its anatomical location and its biochemical and physiological function ${ }^{[2]}$. Drug and its active metabolite induced different appearance on liverat cellular level as well as genetic levelExtensive use of drugs even at therapeutic level damage liver in susceptible individuals ${ }^{[3]}$ [Figure1, Figure 2].

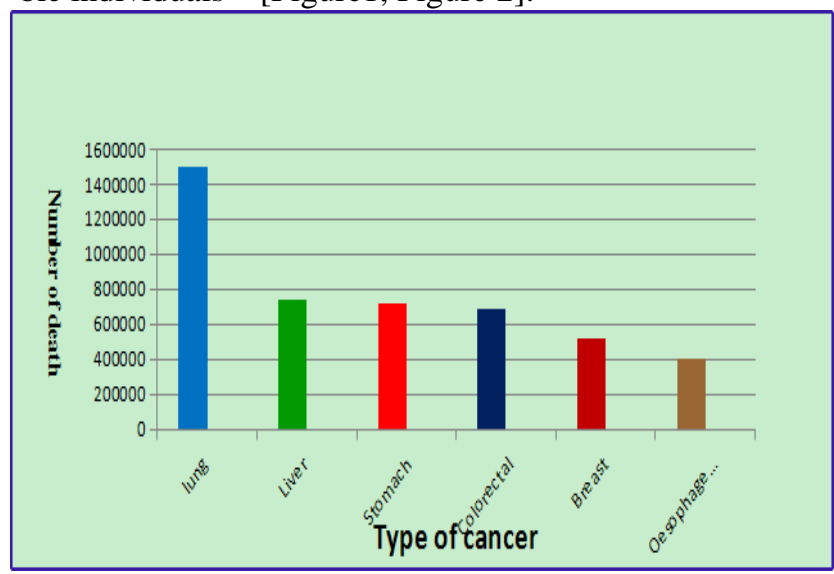

Figure 1; Number of death due to cancer (Total=8.2 million death).

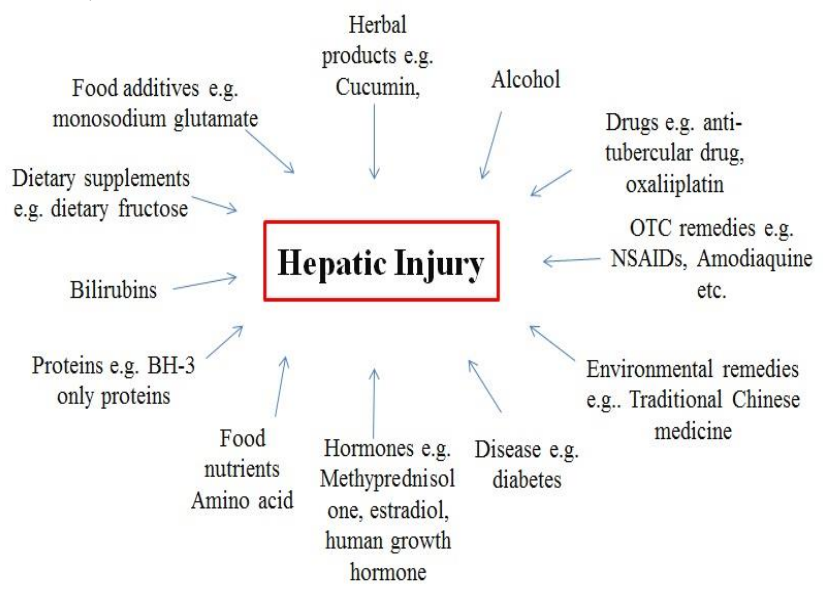

Figure 2; Figure illustrate Common factors affecting liver damage OTC (over the counter); BH-3 (B-cell lymphoma-2 homology $y_{3}$-only members of the B-cell lymphoma-2 protein family).

\section{Types of Hepatotoxicity}

\subsection{Hepatitis}

Hepatitis is the most common disease of liver inflammation. Hepatitis viruses are the most common cause of hepatitis in the world but other infections can also cause hepatitis such as toxic substances (e.g. alcohol,

Copyright (C) 2018 Richa Sachan et al.

doi: 10.24294/as.v1i3.903

EnPress Publisher LLC.This work is licensed under the Creative Commons Attribution-NonCommercial 4.0 International License (CC BY-NC 4.0). http://creativecommons.org/licenses/ by/4.0/ 
certain drugs), and autoimmune diseases. There are mainly 5 hepatitis virus assigned as A, B, C, D and E among which particularly due to $\mathrm{B}$ and $\mathrm{C}$, more than 1 million people die each year (WHO, 2014). Viral infection generally causes inflammatory reaction marked by release of cytokines and chemokines which may lead to cancer development ${ }^{[4]}$. Inflammation induced oxidative stress acquire Kupffer cells to promote stellate cells activation via $\mathrm{NF}-\kappa \mathrm{B}$ and $\mathrm{AP} 1$. Continual activation of these genes results in cirrhosis, fibrosis and severe liver damage leading to development of $\mathrm{HCC}^{[5,6]}$.

\subsection{Cirrhosis}

Cirrhosis of liver is an advanced and consequence stage of liver diseases. Excessive use of alcohol and chronic infection with hepatitis viruses (such as hepatitis $\mathrm{B}$ and hepatitis $\mathrm{C}$ ) are the most common causes of cirrhosis.

\subsection{Non -alcoholic fatty liver disease (NAFLD)}

NAFLD is metabolic disorder commonly observed in obese and diabetic patients ${ }^{[7]}$. Insulin resistance is a key pathogenic factor resulting in hepatic fat accumulation. The exact mechanism of hepatic triglyceride accumulation and subsequent hepatocellular damage are incompletely understood. Hepatic triglyceride accumulation subsequently leads to hepatic insulin resistance by interfering with tyrosine phosphorylation of insulin receptor substrates 1 and $2^{[8]}$. This may exacerbate overall insulin resistance ${ }^{[9,10]}$.

\subsection{Cholestasis}

Disruption or failure of bile formation is a pathophysiological process termed as cholestasis. Cholestasis can be defined by three ways like: biochemical, physiological and morphological. In biochemical condition, altered serum constitute observed in cholestasis e.g. hyperbilirubinemia, bile academia and elevated enzymes such as alkalinephosphatase and gamma glutamyl transpeptidase. In physiological condition, reduced bile flow is observed. Morphologically, cholestasis characterized by presence of greenish yellow-orange waxy plugs in hepatocellular canaliculi most evident in the centrilobular areas in many species. This change is often observed by deformation and loss of canalicularmicrovilli ${ }^{[11,12]}$.

\subsection{Steatosis}

Abnormal retention of lipid within the liver cells lead to generation of Steatosis. Type 2 diabetes, obesity and Steatosis are closely related with each other ${ }^{[9]}$. Multiple factors worked together for the development of fatty liver disease. The mechanism of lipid accumulation is not fully understood but probably relate to alterations of the pathways of uptake, synthesis, degradation, or secretion in hepatic lipid metabolism resulting from insulin resistance. Acute exposure of many chemicals e.g. carbon tetra chloride and several drugs e.g. aspirin as well as alcohol can induce Steatosis ${ }^{[8,13,14]}$.

\section{Risk Factors}

\subsection{Age}

Generally old age is relatively at high liver damage risk than other ages. The increased risk of drug induced liver damage in elderly carries some biological changes in absorption, distribution, metabolism and elimination. Older age was a predictor of cholestatic expression of drug induced liver damage regardless of the type of drug involved $^{[15,16]}$ [Figure 2].

\subsection{Gender}

The research studies clearly pointed towards the women at higher risk for drug induced liver diseases. A study conducted in Japan and Sweden clearly support the percentage of liver injury is $8.7 \%$ in children ranging from 3 to 17 years $^{[17,18]}$ [Figure 2].

\subsection{Alcohol}

Several studies reported the risk of developing liver damage accelerate with the increased alcohol consumption. A lot of studies support the positive relationship between alcohol intake and liver cancer yet its exact role is not fully understood ${ }^{[19-21]}$ [Figure 2].

\subsection{Medication interaction}

Concomitant administration of drugs sometime results in interaction which is complex, challenging and complicates causality assessment ${ }^{[22,23]}$. The administration of drugs simultaneously may have mutual effects such as drugs can be synergistic or antagonistic for liver damage. Antibiotic are the most common cause of liver injury in the United States and Europe ${ }^{[24]}$ [Figure 2].

\subsection{Nutrition}

Deficiency of nutrition may initiate liver disorder as reported in patients with HIV, tuberculosis or alcoholism. It may be due to reduced hepatic glutathione in liver tissues of these patients ${ }^{[25,26]}$ [Figure 2]. 


\subsection{Genetic polymorphism}

Genetic polymorphism of cytochrome enzyme and protein involved in the metabolism of drugs are important predisposing factors in liver diseases. Slow acetylation status has increased and severity of anti-tubercular drug induced hepatotoxicity ${ }^{[27,28]}$ [Figure 2].

\subsection{Pre-existing liver disease}

Previous studies showed that there is no risk of drug induced liver disease in patients having chronic liver disease. The study performed in Spain and United State have not shown that alcohol consumption increase the severity or chronicity of idiosyncratic drug induced liver disease $^{[29]}$ but recent data suggest that presence of fatty liver disease or chronic viral hepatitis may stimulate the drug induced liver disease ${ }^{[30]}$ [Figure 2].

\section{Chemicals induced Hepatotoxi- city}

\subsection{Alcohol}

Consumption of chronic heavy alcohol developed serious health problems including severe liver diseases including fatty liver, alcoholic hepatitis, fibrosis/ cirrhosis, and hepatocellular carcinoma ${ }^{[31]}$. In a report published by WHO, $70 \%$ of mortality due to liver disease is directly related to alcohol. Alcohol consumption leads to liver injury mainly through endotoxin, oxidative stress and inflammation. The metabolism of alcohol in liver occurred by oxidation mainly supported by alcohol dehydrogenase. Since liver is mainly responsible for metabolizing ingested alcohol; therefore it is more susceptible to alcohol related injury ${ }^{[32]}$. Chronic alcohol consumption inhibits hepatic alcohol dehydrogenase and induced biochemical changes mainly cytochrome P450 2E1 isozyme. Both, ADH- and CYP2E1 catalyzed oxidation of ethanol are shown to be associated with generation of acetaldehyde (a reactive aldehyde that binds to cellular proteins and DNA) and/or reactive oxygen spe- cies (ROS) causing peroxidation of unsaturated lipids and oxidation of proteins and DNA. Such reactions alter systemic redox balance by reducing anti-oxidative capacity [such as glutathione (GSH) depletion] resulting in enhanced oxidative stress. However, it is not well understood whether generation of acetaldehyde and ROS, and depletion of GSH, or both are responsible for oxidative stress in liver disease related to chronic alcohol consumption $^{[33,34]}$.

\section{2 $\mathrm{CCl}_{4}$}

Carbon tetra chloride in one of the most extensively used toxicant for inducing liver injury for mutagenicity and DNA damage study in animals. Hepatic microsomal enzyme (CYP2E1) metabolized carbon tetra chloride to degraded metabolites, trichloromethyl $(\mathrm{CCl} 3)$ and trichloromethyl peroxyl (CCl3O2) which is mainly responsible for hepatotoxicity ${ }^{[35]}$. These metabolites are unstable radicals and show strong binding affinity towards protein and lipids in the cell membrane or removing a hydrogen atom from an unsaturated lipid, there by triggering lipid peroxidation and causing liver damage ${ }^{[36,37]}$.

\subsection{NSAIDs}

NSAIDs are the most commonly prescribed drug for the treatment of rheumatic arthritic disease and other chronic inflammatory disorders ${ }^{[38]}$. NSAIDs which mostly influence to produce toxicity are nimesulide, diclofenac and sulindac. NSAIDs are associated with idiosyncratic hepatotoxicity about 19/100,000 treated individual with elevation of serum transaminase to hepatocellular or cholestatic injury and occasionally to fatal hepatitis. Drug induced liver injury is commonly classified in to intrinsic like idiosyncratic hepatotoxicity which is further classified as allergic and non-allergic and other clinical classification differentiate e.g. hepatocellular, cholestatic or mixed liver enzyme patterns, histological criteria, acute vs. chronic onset, or severity ${ }^{[39,40]}$ [Table $1]$. 


\begin{tabular}{|l|l|l|}
\hline Associated Drugs & Signature disease & Reference \\
\hline Methotrextate, Tetracycline, Valproic Acid, & Steatosis & 78 \\
\hline Paracetamol, Acetaminophen, Isoniazid, Methyldopa, Troglitazone, & Hepatitis & 79, \\
\hline $\begin{array}{l}\text { Thioacetamide, } \\
\text { Amiodarone, tamoxifen, valproic acid, Perhexiline Male- } \\
\text { ate,Amoidarone,Estrogens,Calcium channel blockers }\end{array}$ & Steatohepatitis & 70,09 \\
\hline $\begin{array}{l}\text { Methotrextate, Corticosteroids, Colchicine, Angiotensin inhibitors, To- } \\
\text { copherol, }\end{array}$ & Fibrosis & 80,81 \\
\hline $\begin{array}{l}\text { Amoxicillin/Clavuanate, Clopidogrel, Estrogen, Oral contraceptive, Eryth- } \\
\text { romycin, Amitryptylin, Allopurinol, Captopril, Carbamazepine,ACE inhib- } \\
\text { itors }\end{array}$ & Cholestasis & 82 \\
\hline $\begin{array}{l}\text { Statins,Isoniazid,Acetaminophen, Aspirin, Allopurinol, Ciprofloxacin, } \\
\text { Rifampin, Tetracycline, Imatinib, Losartan }\end{array}$ & Hepatocellular & 83 \\
\hline
\end{tabular}

Table 1. Clinical and pathological symptoms of drug-induced liver diseases

\subsection{Paracetamol (PCM)}

PCM is most widely used analgesic and antipyretic agent which induced liver injury in dose dependent manners. The reactive metabolite, $\mathrm{N}$-acetyl-p-benzoquioneimine (NAPQI) covalently binds to glutathione protein to form conjugate which lead to irreversible hepatocyte injury and necrosis by different mechanism. NAPQI bind to sulfydryl group of glutathione causing depletion of hepatic anti-oxidative capacity and oxidative damage of various cell components which result in necrosis ultimately result in death ${ }^{[41,42]}$ [Table $1]$.

\subsection{Thioacetamide}

In many experiments, Thioacetamide is used for induction of liver fibrosis and cirrhosis. It induced liver injury by oxidative stress and mainly due to formation of toxic metabolite Thioacetamide-S-oxide, formed during its biotransformation by the microsomal flavine adenine dinucleotide (FAD)-containing monooxygenase ${ }^{[43,44]}$. Oxidative bioactive Thioacetamide is the toxic metabolite responsible for protein covalent binding that leads to toxicity $^{[45]}$ [Table 1].

\subsection{Azathioprine}

Azathioprine is prodrug for mercaptopurine, used as an immunosuppressive drug used in organ transplantation and autoimmune disease like refractory severe rheumatoid arthritis, systemic lupus erythematosus, psoriasis and inflammatory bowel disease ${ }^{[46]}$. Although it has several beneficial effects yet its use is limited due to harmful effect on liver and bone marrow. The mechanisms of azathioprine include depletion of GSH due to free radical formation leading to mitochondrial injury, depletion of ATP and finally lead to death by necrosis thus causing liver injury ${ }^{[47]}$ [Table 1].

\subsection{Anti-tubercular agent}

The three key tuberculosis drug isoniazid, pyrazinamide and rifampicin play a central role in inducing hepatotoxicity. A meta-analysis of studies involving the use of combinations of antituberculosis drug regimens mainly in adults has shown an incidence rate of liver toxicity of $2.6 \%$ with isoniazid and rifampicin co-administration Isoniazid is a prodrug which is activated by catalase-peroxidase enzyme ${ }^{[48]}$. This drug is mainly metabolized by the microsomal enzyme, CYP2E1 by acylation in liver. The principal metabolite, N-hydroxy -acetyl hydrazine undergoes further dehydration to form toxic metabolite, aetyl diazine which further break in to acetylonium ion,acetyl radical and ketenes which bind to hepatic macromolecules and induce liver injury ${ }^{[49]}$ [Table 1].

Rifampicin is another drug used in treatment of tuberculosis, also cause liver injury is metabolized to desacetyl rifampicin by desacetylation and further hydrolyzed to 3-formyl rifampicin which is the main inducing agent for liver injury ${ }^{[50]}$. 


\section{Mechanisms of Hepatotoxicity}

Since liver received blood majorly from gastrointestinal viscera, which also bring drugs and xenobiotics in concentrated form, Because of an important target of metabolism and unique relationship with gastrointestinal tract, it's become a target for toxicity of drugs, xenobiotics and oxidative stress. Hepatic injury may cause due to direct cell toxicity of chemicals or metabolic. Hepatic injury occurred by different mechanism include bile acid induced apoptosis during cholestasis, pathohysiological effect of mitochondrial dysfunction and cell damage by reactive oxygen species and nitrogen species.

\subsection{Bile acid induced hepatocyte apoptosis}

Bile acid only synthesized by liver, important for metabolism of fatty acid and lack of bile acid lead to a pathophysiological headway termed as cholestasis. Accumulation of bile acid during cholestasis leads to hepatocyte apoptosis due to stimulation of magnesium ion dependent endonuclease. Hydrophobic bile acids are especially hepatotoxic, and they accumulate in the liver in cholestatic disorder. The failure to secret bile acids in to the bile results in liver injury, cirrhosis and death from liver failure ${ }^{[51]}$. Apoptosis mainly occurred by two path ways (1) death receptor pathway and (2) the mitochondrial pathway. To determine if death-receptor pathways contribute to bile acid-mediated apoptosis, hepatocytes from tumor necrosis factor-receptor 1 (TNF-R1) and Fas-deficient mice were exposed to GCDC. TNF-R1 and Fas are the predominant death receptors expressed by hepatocytes. Hepatocytes from Fas-deficient lpr mice were resistant to GCDC-mediated apoptosis, whereas TNF-R1-deficient hepatocytes readily underwent apoptosis. Unexpectedly, hepatocytes from Fas ligand-deficient mice were also sensitive to GCDC stimulated apoptosis. These data implicate ligand-independent Fas-mediated apoptosis as a contributing mechanism for bile acid-related liver injury. To further test this concept, the bile ducts of wild type and Fas-deficient mice were ligated to produce severe extrahepatic cholestasis. Caspase 8, an initiator cysteine-aspartate protease in apoptosis, was activated in wild type animals but not Fas-deficient mice. Bile duct ligated Fas-deficient animals also had less apoptosis, decreased liver injury, and improved survival as compared to wild type mice. Thus,
Fas activation appears to play a dominant role in bile acid cytotoxicity $^{[52,53]}$ [Figure 3,4].

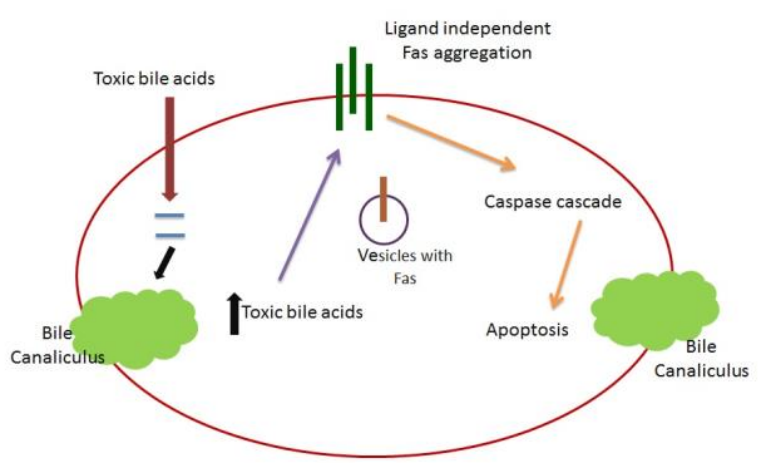

Figure 3; Bile acid-induced hepatocyte apoptosis; Bile acids are normallysecreted rapidly from hepatocytes by transporters located in the canalicularmembrane. In cholestasis, secretion is impaired, resulting in elevated concentrationsof toxic bile acids (TBA) within hepatocytes. At pathophysiologic concentrations, toxic bile acids trigger translocation of intracellular Fas bearing vesicles to the plasma membrane where they self-aggregate in the absence of ligand. Activated Fas receptor complexes on the plasma membrane then cause caspase 8 activation and an apoptotic cascade.

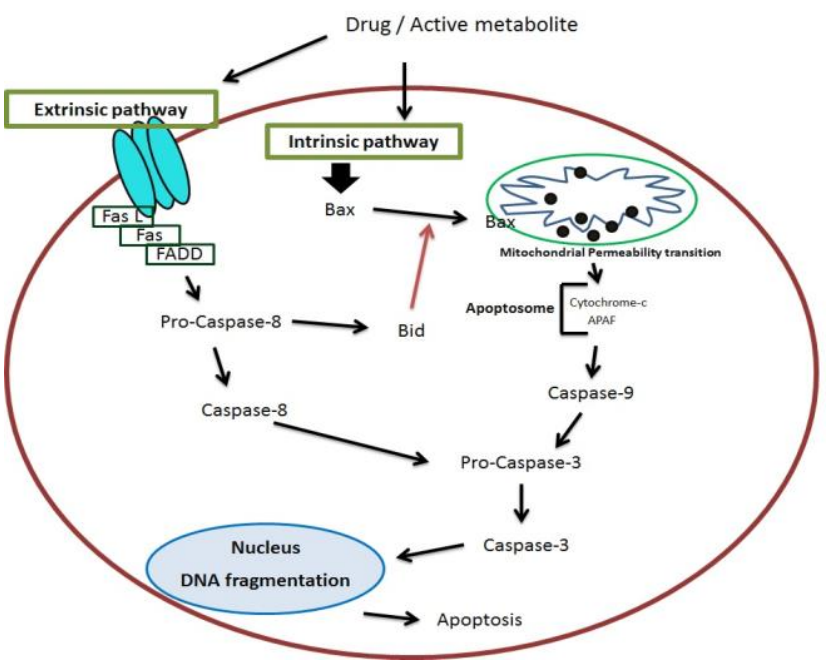

Figure 4; Drug induced mitochondrial dysfunction APAF (Apoptotic protease activating factor);FADD (Fas-Associated protein with Death Domain).

\subsection{Drug induced mitochondrial dysfunction}

Finding the mechanism of drug induced liver injury is a challenge because it always involves several mechanism, regulatory system and risk factor complex interaction. Drug induced liver injury involve intrinsic and extrinsic pathway emphasizing the central role of mitochondria for the mechanisms leading to apoptosis. Drug 
or its active metabolites create direct cell stress by which it target mitochondrial function. Reactive metabolites can exert initial cell stress through a wide range of mechanisms including depletion of glutathione (GSH), or binding to enzymes, lipids, nucleic acids and other cell structures $^{[54]}$ [Figure 3,4].

\section{Biomarkers of Hepatotoxicity}

\subsection{Serum biomarker}

\subsubsection{ALT}

The most widely used clinical biomarker of liver disease in preclinical species and humans is ALT. Alanine is present in liver in higher concentration and ALT is responsible for its metabolism (transamination ${ }^{[55]}$.When hepatocyte liver injury occurs, the liver abundant ALT will leak in to the extracellular space and enter the blood, wherein it shows a slow clearance rate with a half-life of approximately $42 \mathrm{hr}$. The typical reference range is 7-35 IU/L in females and 10-40IU/L in males. An elevation of serum ALT activity is often reflective of liver damage. Unfortunately, extra-hepatic injury such as muscle injury can also lead to elevation in ALT making ALT not entirely hepato-specific. In addi- tion, fenofibrate was found to increase ALT gene expression in the absence of apparent liver injury and hepatotoxin microcystin-LR was reported to suppress Alt gene expression $^{[56,57]}$ [Figure 5,6$]$ [Table 2].

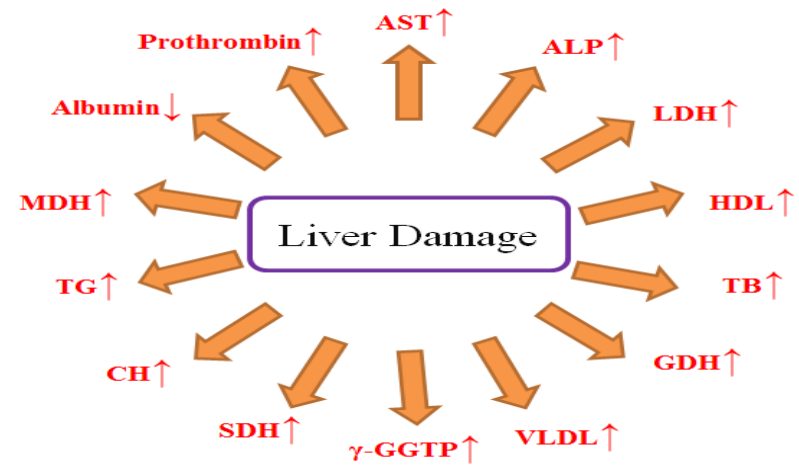

Figure 5; Biochemical indicators of hepatotoxicity $(\uparrow)$ increased value during hepatotoxicity, $(\downarrow)$ decreased value during hepatotoxicity)ALP(Alanine phosphate);AST (Aspartate aminotransferase); $\mathrm{CH}$ (cholesterol); $\gamma$-GGTP ( $\gamma$-glutamyl transpeptidase); GDH (glutamate dehydrogenase); HDL (high density lipoprotein); LDL (low density lipoprotein); MDH (malate dehydrogenase); SDH (sorbitol dehydrogenase); TB(Total bilirubin);TG(triglyceride);VLDL (very low density lipoprotein).

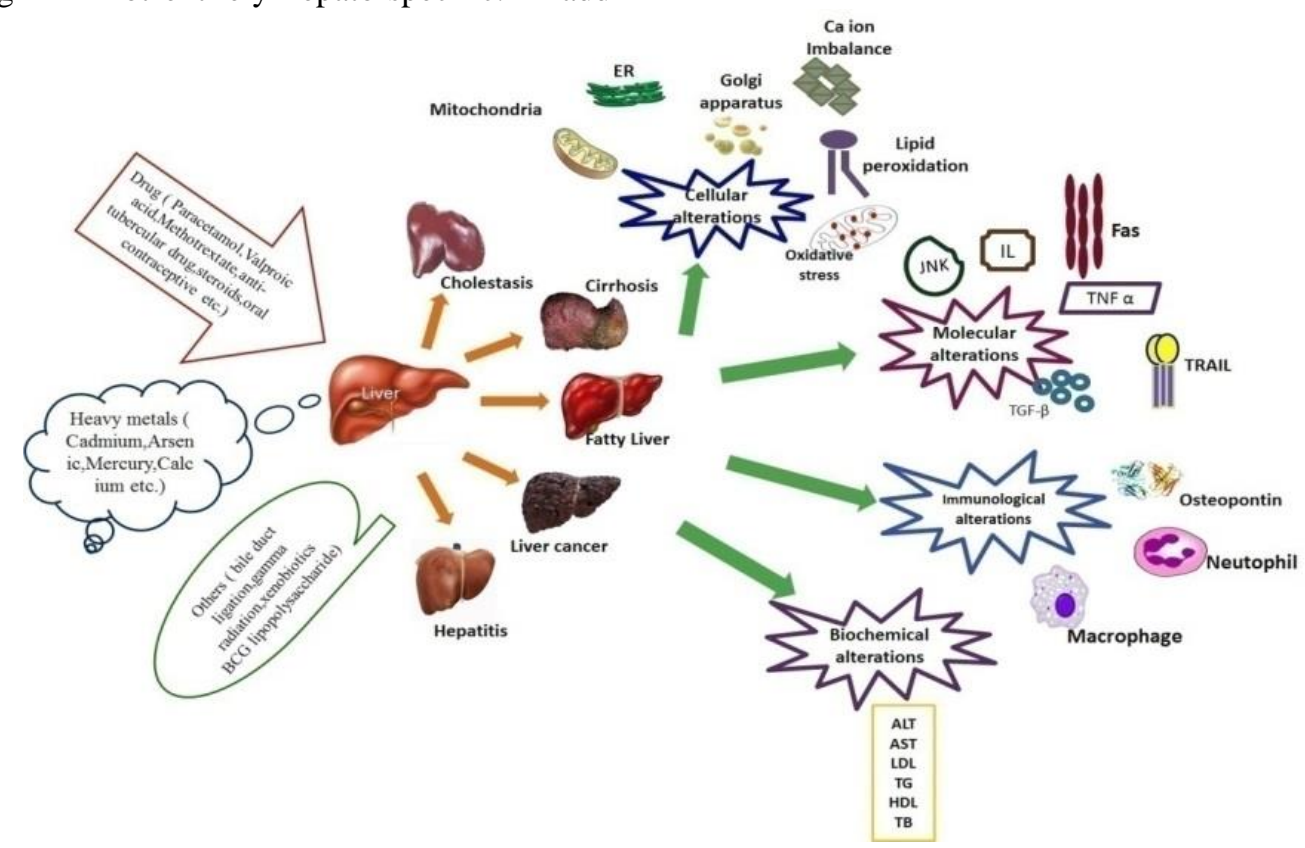

Figure 6. Figure illustrate cellular, molecular, immunological and biochemical alteration during hepatotoxicity induced by various factors. ALT (Alamine aminotransferase); AST (Aspartate aminotransferase); LDL (low density lipoprotein); HDL (high density lipoprotein); TB (Total bilirubin); TG (triglyceride); JNK (C-Jun N-terminal kinase; IL (interleukins); TNF- $\alpha$ (Tumor necrosis factor- $\alpha$ ); ER (endoplasmic reticulum); TRAIL (Tumor necrosis factor-related apoptosis inducing ligand). 


\begin{tabular}{|c|c|c|c|c|c|c|}
\hline $\begin{array}{l}\text { Bio- } \\
\text { marker }\end{array}$ & Specific function & $\begin{array}{l}\text { Tissue Lo- } \\
\text { calization }\end{array}$ & Injury & $\begin{array}{l}\text { Specific damage } \\
\text { marker }\end{array}$ & Comments & $\begin{array}{l}\text { Refer- } \\
\text { ences }\end{array}$ \\
\hline ALT & $\begin{array}{l}\text { Transamination in } \\
\text { alanine cycle }\end{array}$ & $\begin{array}{l}\text { Primarily } \\
\text { localized in } \\
\text { liver }\end{array}$ & $\begin{array}{l}\text { Elevated in } \\
\text { blood due to } \\
\text { liver necro- } \\
\text { sis and with } \\
\text { heart and } \\
\text { skeletal } \\
\text { muscle inju- } \\
\text { ry } \\
\text { ( necrosis) }\end{array}$ & $\begin{array}{l}\text { Hepatocellular } \\
\text { necrosis }\end{array}$ & $\begin{array}{l}\text { Commonly used to } \\
\text { assess hepatocellular } \\
\text { injury }\end{array}$ & $55,56,57$ \\
\hline AST & $\begin{array}{l}\text { Catalyzes the re- } \\
\text { versible transfer of } \\
\text { an } \alpha \text {-amino group } \\
\text { between aspartate } \\
\text { and glutamate }\end{array}$ & $\begin{array}{l}\text { Localized in } \\
\text { heart, brain, } \\
\text { skeletal } \\
\text { muscle and } \\
\text { liver }\end{array}$ & $\begin{array}{l}\text { Elevated in } \\
\text { blood due to } \\
\text { liver or ex- } \\
\text { trahepatic } \\
\text { tissue injury }\end{array}$ & $\begin{array}{l}\text { Hepatocellular } \\
\text { necrosis }\end{array}$ & $\begin{array}{l}\text { Less specific than } \\
\text { ALT }\end{array}$ & 56,58 \\
\hline TBL & $\begin{array}{l}\text { Main physiologic } \\
\text { role as an antioxi- } \\
\text { dant }\end{array}$ & $\begin{array}{l}\text { Taken up, } \\
\text { conjugated } \\
\text { in liver and } \\
\text { secreted in } \\
\text { bile }\end{array}$ & $\begin{array}{l}\text { increased } \\
\text { markers of } \\
\text { hepatobiliary } \\
\text { injury and } \\
\text { liver } \\
\text { function, due } \\
\text { to } \\
\text { hemolysis }\end{array}$ & $\begin{array}{l}\text { Cholestasis, } \\
\text { biliary, } \\
\text { liver function }\end{array}$ & $\begin{array}{l}\text { Conventional biliary } \\
\text { injury,in conjunction } \\
\text { with } \\
\text { ALT,betterbindicator } \\
\text { of disease severity } \\
\text { in humans }\end{array}$ & $56,57,58$ \\
\hline ALP & $\begin{array}{l}\text { Remove phosphate } \\
\text { group from mole- } \\
\text { cules such as pro- } \\
\text { teins,nucleotides } \\
\text { etc. }\end{array}$ & $\begin{array}{l}\text { Broad tissue } \\
\text { localization }\end{array}$ & $\begin{array}{l}\text { Marker of } \\
\text { hepato } \\
\text { biliary injury }\end{array}$ & Cholestasis & $\begin{array}{l}\text { Conventional biliary } \\
\text { injury, associated } \\
\text { with } \\
\text { drug induced cho- } \\
\text { lestasis in humans }\end{array}$ & 60 \\
\hline GGT & $\begin{array}{l}\text { Involve in transfer } \\
\text { of amino acids } \\
\text { across the cellular } \\
\text { membrane and } \\
\text { glutathione metab- } \\
\text { olism }\end{array}$ & $\begin{array}{l}\text { Activity } \\
\text { localized to } \\
\text { kidney > } \\
\text { liver, pan- } \\
\text { creas }\end{array}$ & $\begin{array}{l}\text { Marker of } \\
\text { hepatobiliary } \\
\text { injury }\end{array}$ & Cholestasis, biliary & $\begin{array}{l}\text { Conventional biliary } \\
\text { injury, high sensitiv- } \\
\text { ity in humans, ele- } \\
\text { vation caused by } \\
\text { alcohol/ heart dis- } \\
\text { ease }\end{array}$ & 57 \\
\hline Albumin & $\begin{array}{l}\text { Regulate colloidal } \\
\text { osmotic pressure of } \\
\text { blood }\end{array}$ & $\begin{array}{l}\text { Main con- } \\
\text { stituent of } \\
\text { serum total } \\
\text { protein }\end{array}$ & $\begin{array}{l}\text { Decreased in } \\
\text { blood with } \\
\text { chronic liver } \\
\text { disease }\end{array}$ & Liver function & $\begin{array}{l}\text { Liver fails to syn- } \\
\text { thesize enough pro- } \\
\text { tein, especially al- } \\
\text { bumin }\end{array}$ & 84 \\
\hline $\begin{array}{l}\text { Cholesterol/ } \\
\text { triglycerides }\end{array}$ & $\begin{array}{l}\text { Build and maintain } \\
\text { cell membrane as } \\
\text { well as fluidity of } \\
\text { membrane }\end{array}$ & $\begin{array}{l}\text { Cell mem- } \\
\text { brane local- } \\
\text { ization }\end{array}$ & $\begin{array}{l}\text { Increased in } \\
\text { blood due to } \\
\text { the failure of } \\
\text { bile elimina- } \\
\text { tion }\end{array}$ & Liver function & $\begin{array}{l}\text { Liver fails to re- } \\
\text { move them to bile } \\
\text { ducts }\end{array}$ & 85 \\
\hline
\end{tabular}




\begin{tabular}{|l|l|l|l|l|l|}
\hline Urobilinogen & & $\begin{array}{l}\text { Low level in } \\
\text { urine due to } \\
\text { biliary ob- } \\
\text { struction }\end{array}$ & Liver function & $\begin{array}{l}\text { Colorless product of } \\
\text { bilirubin reduction, } \\
\text { similar role to bili- } \\
\text { rubin }\end{array}$ & 86 \\
\hline
\end{tabular}

Table 2. Summary of current clinical biomarkers of liver toxicity

ALP (Alanine phosphate); ALT(Alanine aminotransferase); AST (Aspartate aminotransferase); GGT (Gamma glutamyl transferase); TBL(Total bilirubin)

\subsubsection{Aspartate amino transferase (AST)}

In the last 30 years, AST has also been proved as a standard biomarker for identification of severity of various liver diseases ${ }^{[56,58]}$. Similar to ALT, AST is responsible for metabolism (transamination of aspartate).Even though the sensitivity of the AST test is believed to be lower than that of ALT because of low mitochondrial enzyme, it is still a widely used liver biomarker ${ }^{[57]}$ [Figure 5, 6] [Table 2].

\subsubsection{Alkaline phosphate activity (ALP)}

ALP is mainly present in cell membranes in multiple tissues mainly in hepatocytes. At alkaline $\mathrm{pH}$, it hydrolyzes monophosphates. Several isoenzymes have been identified in different organs like intestinal, kidney and placental forms. Identification of bile duct blocked when ALP concentration increased. It is also identified as major diagnostic biomarker as recommended as FDA guidance and by clinicians ${ }^{[57]}$ [Figure 5, 6] [Table 2]

\subsubsection{Total bilirubin}

Total bilirubin is a composite of indirect (nonhepatic) and direct (hepatic) bilirubin. This product of hemoglobin degradation is a marker of hepatobiliary injury, especially cholestasis and biliary effects ${ }^{[59]}$. In acute human hepatic injury, total bilirubin can be a better indicator of disease severity compared to ALT. Bilirubin may also be increased due to non-hepatic causes such as he- molysis. Analysis of indirect compared to direct bilirubin does not necessarily add information in routine assessment when compared to total bilirubin ${ }^{[60]}$ [Figure 6] [Table 2].

\subsubsection{Gamma-glutamyl transferase activity} (GGT)

Gamma-glutamyl transferase (GGT) activity is localized to liver, kidney, and pancreas tissues, yet enzyme concentration in liver is low compared to kidney GGT has multiple functions including catalytic transfer of gamma-glutamyl groups to amino acids and short peptides hydrolysis of GSH to a gamma-glutamyl moiety and cysteinly glycine in GSH and GSH conjugate catabolism. GGT activity is a marker of hepatobiliary injury, especially cholestasis and biliary effects ${ }^{[61]}$ [Figure 6] [Table 2].

\subsubsection{Bile acid}

Bile acids functionally contribute to the catabolism and elimination of cholesterol; are the primary determinant of bile flow; regulate pancreatic secretions; and release of GI peptides, and contribute to the digestion and absorption of fat (and indirectly fat-soluble vitamins) in the small intestine. Total bile acids are also implicated in various signal transduction pathways and are elevated with liver injury and functional change; it can be influenced by diet and fasting ${ }^{[62,63]}$ [Figure 6] [Table 2, 3]. 


\begin{tabular}{|c|c|c|c|c|}
\hline Biomarker candidate & $\begin{array}{l}\text { Bio-fluid } \\
\text { evaluated }\end{array}$ & Origin & Proposed indication & References \\
\hline Interleukin-1 & Plasma & Produced by a variety of cells & $\begin{array}{l}\text { Cellular response to } \\
\text { tissue damage }\end{array}$ & 87 \\
\hline $\begin{array}{l}\text { Glutathione S-transferase } \\
\text { P-form }\end{array}$ & serum & Present in the hepatocytes & Hepatocellular injury & 88 \\
\hline Glutamate dehydrogenase & serum & $\begin{array}{l}\text { Primarily found in the liver } \\
\text { and to a lesser degree in the } \\
\text { kidney and skeletal muscle }\end{array}$ & $\begin{array}{l}\text { Hepatocellular ne- } \\
\text { crosis }\end{array}$ & 88 \\
\hline Malate dehydrogenase & serum & $\begin{array}{l}\text { Localized in the mitochondria } \\
\text { and extra mitochondrial com- } \\
\text { partment, found primarily in } \\
\text { the liver but also in skeletal } \\
\text { muscle, heart and brain }\end{array}$ & $\begin{array}{l}\text { Hepatocellular ne- } \\
\text { crosis }\end{array}$ & 88 \\
\hline Purine nucleoside phosphorylase & serum & $\begin{array}{l}\text { Primarily in the liver but also } \\
\text { present in heart muscle and } \\
\text { brain; mainly in the cytoplasm } \\
\text { of endothelial cells, kupffer } \\
\text { cells, and hepatocytes }\end{array}$ & $\begin{array}{l}\text { Hepatocellular ne- } \\
\text { crosis }\end{array}$ & 46 \\
\hline Paraoxanase 1 & serum & $\begin{array}{l}\text { Produced primarily in the liver } \\
\text { but also found in the kidney, } \\
\text { brain and lung }\end{array}$ & $\begin{array}{l}\text { Hepatocellular ne- } \\
\text { crosis }\end{array}$ & 20 \\
\hline Glutathione S-transferase alpha & serum & Liver specific & $\begin{array}{l}\text { Hepatocellular ne- } \\
\text { crosis }\end{array}$ & 81 \\
\hline Apopipoprotein E & serum & $\begin{array}{l}\text { Produced in the liver but also } \\
\text { found in the brain and kidney }\end{array}$ & $\begin{array}{l}\text { Hepatocellular ne- } \\
\text { crosis }\end{array}$ & 56 \\
\hline Bile acids & $\begin{array}{l}\text { Urine } \\
\text { serum }\end{array}$ & $\begin{array}{l}\text { Synthesized primarily in the } \\
\text { liver }\end{array}$ & $\begin{array}{l}\text { Liver dysfunction } \\
\text { including intrahe- } \\
\text { patic cholestasis }\end{array}$ & 89 \\
\hline Steroids & Urine & Metabolites of Cholesterol & $\begin{array}{l}\text { Oxidative stress and } \\
\text { liver damage }\end{array}$ & 90 \\
\hline Acylcarnitines & $\begin{array}{l}\text { Urine } \\
\text { serum }\end{array}$ & $\begin{array}{l}\text { Located in the heart, muscle, } \\
\text { brain, liver and kidney }\end{array}$ & $\begin{array}{l}\text { Failure of fatty acid } \\
\text { oxidation }\end{array}$ & 91 \\
\hline miRNA-122 & Plasma/Serum & Liver specific expression & $\begin{array}{l}\text { Viral-, alcohol- and } \\
\text { chemical induced } \\
\text { liver injury }\end{array}$ & 92 \\
\hline miRNA-192 & Plasma/Serum & Liver specific expression & $\begin{array}{l}\text { Chemical induced } \\
\text { liver injury }\end{array}$ & 92 \\
\hline miRNA-291a-5p & Urine & Unknown & $\begin{array}{l}\text { Chemical induced } \\
\text { liver injury }\end{array}$ & 93 \\
\hline
\end{tabular}

Table 3. Summary of emerging biomarkers of liver toxicity

\subsection{Genomic approach:}

Genomics is a discipline in genetics that applies recombinant DNA, DNA sequencing methods, and bioinformatics to sequence, assemble, and analyze the function and structure of genomes (the complete set of DNA within a single cell of an organism $)^{[64]}$. In the identification of drug induced liver injury, the use of genomic approach to determine patterns of changes in 
mRNA transcripts, introduced as toxicio-genomics grab the attention ${ }^{[65]}$ [Table 4].

\begin{tabular}{|l|l|l|l|l|}
\hline $\begin{array}{l}\text { Types of hepa- } \\
\text { totoxicity }\end{array}$ & $\begin{array}{l}\text { Drug associ- } \\
\text { ated with } \\
\text { hepatotoxi- } \\
\text { city }\end{array}$ & $\begin{array}{l}\text { Types } \\
\text { of } \\
\text { Hu- } \\
\text { man } \\
\text { study }\end{array}$ & $\begin{array}{l}\text { En- } \\
\text { zyme/H } \\
\text { LA } \\
\text { allele }\end{array}$ & $\begin{array}{l}\text { Refe } \\
\text { renc } \\
\text { e }\end{array}$ \\
\hline Virus & Efavirenz & $\begin{array}{l}\text { Open-1 } \\
\text { abel } \\
\text { trial } \\
\text { (n=15 } \\
\text { 6) }\end{array}$ & CYP2B6 & 94 \\
\hline Drug & $\begin{array}{l}\text { An- } \\
\text { ti-tuberculosis } \\
\text { drug }\end{array}$ & $\begin{array}{l}\text { Cohort } \\
\text { study } \\
\text { (n=89) }\end{array}$ & $\begin{array}{l}\text { SLCO1 } \\
\text { B1 } \\
\text { \&LC10 } \\
\text { A1 }\end{array}$ & 95 \\
\hline Drug & $\begin{array}{l}\text { An- } \\
\text { ti-tuberculosis } \\
\text { drug }\end{array}$ & $\begin{array}{l}\text { Case } \\
\text { study } \\
\text { (n=44 } \\
5)\end{array}$ & $\begin{array}{l}\text { IL-4 and } \\
\text { IL-10 }\end{array}$ & 92 \\
\hline Drug & $\begin{array}{l}\text { Isonia- } \\
\text { zid-containing } \\
\text { antituberculo- } \\
\text { sis drug regi- } \\
\text { men }\end{array}$ & $\begin{array}{l}\text { Case } \\
\text { study } \\
\text { (n=33) }\end{array}$ & $\begin{array}{l}\text { cyto- } \\
\text { chrome } \\
\text { P4502E } \\
1\end{array}$ & 96 \\
\hline $\begin{array}{l}\text { Rifampin } \\
\text { osyncratichepa- } \\
\text { titis }\end{array}$ & $\begin{array}{l}\text { Open } \\
\text { zine }\end{array}$ & $\begin{array}{l}\text { SLCO1 } \\
\text { study } \\
\text { (n=27 } \\
3 \text { ) }\end{array}$ & $\begin{array}{l}15 \text { hap- } \\
\text { lotype }\end{array}$ & 97 \\
\hline Drug & $\begin{array}{l}\text { Case } \\
\text { study } \\
\text { (n=71) }\end{array}$ & $\begin{array}{l}\text { HLA-D } \\
\text { R6 }\end{array}$ & 1 \\
\hline
\end{tabular}

Table 4. Select examples of genetic polymorphisms associated with a possible increased risk of hepatotoxicity from specific drugs

\subsection{Proteomics evaluation:}

The qualitative and quantitative proteomics evaluation is an important step to differentiate the protein expression for better understanding of novel protein biomarker in diverse biological function ${ }^{[66,67]}$ [Table 5].

\begin{tabular}{|c|c|c|c|}
\hline Disease & $\begin{array}{c}\text { Man- } \\
\text { ifesta- } \\
\text { tion }\end{array}$ & Biomarker & Reference \\
\hline \multirow{8}{*}{$\begin{array}{c}\text { Nonal- } \\
\text { coholic } \\
\text { fatty }\end{array}$} & \multirow{8}{*}{$\begin{array}{l}\text { In- } \\
\text { flam- } \\
\text { matio } \\
\text { n }\end{array}$} & Ferritin & 66 \\
\hline & & $\begin{array}{c}\text { High sensitivity-reactive } \\
\text { protein }\end{array}$ & \multirow[t]{3}{*}{66,98} \\
\hline & & TNF- $\alpha$ & \\
\hline & & Adipokines & \\
\hline & & Adiponectin & \multirow[t]{3}{*}{66} \\
\hline & & Visfatin & \\
\hline & & Leptin & \\
\hline & & IL-6 & 99 \\
\hline
\end{tabular}

\begin{tabular}{|c|c|c|c|}
\hline \multirow[t]{9}{*}{$\begin{array}{c}\text { liver } \\
\text { disease }\end{array}$} & $\begin{array}{c}\text { Apopt } \\
\text { osis }\end{array}$ & Cytokeratin-18 & \multirow[t]{3}{*}{66} \\
\hline & \multirow{3}{*}{$\begin{array}{l}\text { Oxi- } \\
\text { dative } \\
\text { stress }\end{array}$} & Malonaldehyde & \\
\hline & & TBARS & \\
\hline & & Oxidised (LDL) & 66 \\
\hline & \multirow{5}{*}{$\begin{array}{l}\text { Fibro- } \\
\text { sis }\end{array}$} & Hyaluronic acid & \multirow[t]{5}{*}{66} \\
\hline & & Type IV collagen $S$ & \\
\hline & & Fibronectin, & \\
\hline & & TIMP1 & \\
\hline & & $\begin{array}{l}\text { Procollagen III N pep- } \\
\text { tide }\end{array}$ & \\
\hline
\end{tabular}

Table 5. Select examples of proteomics biomarker along with hepatotoxicity

TNF- $\alpha$ ( Tumor necrosis factor- $\alpha$ ), TBARS (thiobarbituric acid reactive substances),LDL (low density lipoprotein),IL-6 ( Interlekin-6), TIMP1( tissue inhibitor of metalloproteiases)

\subsection{Metabolomics approach:}

Metabolomics involved the measurement of the metabolite pool that exists within a cell or tissues under a particular set of conditions. The metabolic profile is greatly influenced by both genetic and environmental factors, thereby providing phenotypic-specific data that can be evaluated in a longitudinal manner. Metabolomics analyses focus on the discovery of novel, clinically relevant biomarkers in easily obtained bio fluids such as urine and serum ${ }^{[68]}$. As hepatotoxicity is the major cause for drug related adverse events, metabolomics has been employed in multiple preclinical studies to identify more selective markers of drug induced liver injury. Metabolites from several major pathways have been reported in multiple studies ${ }^{[69]}$ [Table 3].

\subsection{Micro RNA as biomarker:}

Micro RNAs are short approx 22 nucleotide, noncoding RNAs which have been recently identified as vital post transcriptional regulators of gene expression in most eukaryotic genome ${ }^{[69,70]}$. The human genome is predicted to encode $\sim 1000 \mathrm{mi}$ RNAs and it is assumed that they can regulate approximately one third of all human transcripts ${ }^{[71]}$. Recent several studies proved mi-RNA as useful noninvasive diagnostic marker and its unique stability with unique position in biofluid including blood and urine in liver diseases ${ }^{[72,73,74,75]}$ [Table 6]. 


\begin{tabular}{|c|c|c|c|}
\hline $\begin{array}{l}\text { mi-RNA bi- } \\
\text { omarker }\end{array}$ & Etiology & Inference & Reference \\
\hline $\operatorname{miR}-224$ & $\operatorname{HCC}(n=19)$ & Up-regulation of miR-224 reflect $\mathrm{HCC}$ & 100 \\
\hline miR-500 & $\mathrm{HCC}(\mathrm{n}=40)$ & $\begin{array}{l}\text { an oncofetal miRNA, highly expressed in fetal liver } \\
\text { aberrantly expressed in HCC }\end{array}$ & 101 \\
\hline miR-338 & $\mathrm{HCC}(\mathrm{n}=20)$ & Down regulation of miR-338 in HCC metastasis & 102 \\
\hline miR-122 & $\begin{array}{l}\text { Hepatitis B viral infection } \\
(\mathrm{n}=83)\end{array}$ & Increase of miR-122 in Hepatitis B viral infection & 71,103 \\
\hline $\begin{array}{l}\text { miR-25, }-92 \mathrm{a}, \\
\text { let7f, miR-375 }\end{array}$ & $\begin{array}{l}\text { Hepatitis B viral infection (n } \\
\approx 150)\end{array}$ & $\begin{array}{l}\text { miR-375 is Hepatitis B viral infection specific and } \\
\text { predicts HCC }\end{array}$ & 73 \\
\hline $\begin{array}{l}\operatorname{miR}-122 \\
\operatorname{miR}-34 a\end{array}$ & $\begin{array}{l}\left.\text { Chronic Hepatitis } \begin{array}{l}\text { C viral } \\
\text { infection }(\mathrm{n}=\end{array}\right) \\
\text { Non-alcoholic fatty liver } \\
\text { and } \\
\text { ease }(\mathrm{n}=34)\end{array}$ & Both display liver damage and fibrosis & 104 \\
\hline miR-885-5p & $\begin{array}{c}\text { HCC,Liver cancer and } \\
\text { Chronic hepatitis } \mathrm{B}(\mathrm{n} \approx 100)\end{array}$ & specifically predict HCC & 104 \\
\hline $\begin{array}{l}\text { miR-122,-222 ,- } \\
223 \\
\quad \text { miR-21 }\end{array}$ & $\begin{array}{l}\text { HBV patients } \\
\text { without HCC }(n=48) \text { and } \\
\text { HBV patients with HCC }\end{array}$ & miR-122 up-regulation in $\mathrm{HBV}$ patients with $\mathrm{HCC}$ & 105 \\
\hline $\begin{array}{l}\text { miR-29, } \\
\text { miR-133a }\end{array}$ & $\mathrm{HCC}$ & 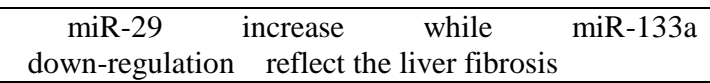 & 106 \\
\hline $\begin{array}{l}\mathrm{miR}-122, \quad \mathrm{miR} \\
-192\end{array}$ & $\begin{array}{l}\text { Acetaminophen-induced } \\
\text { acute liver injury }\end{array}$ & Up-regulation reflect liver damage & 107 \\
\hline $\begin{array}{l}\text { miR-21, } \mathrm{miR} \\
-122, \mathrm{miR}-223\end{array}$ & $\begin{array}{l}\text { Hepatocellular carcinoma, } \\
\text { Chronic hepatitis b virus }(\mathrm{n} \approx \\
\text { 150) }\end{array}$ & $\begin{array}{l}\text { All increased in Hepatocellular carcinoma, } \\
\text { Chronic hepatitis b virus }\end{array}$ & 108 \\
\hline $\begin{array}{l}\text { miR-122, } \\
\text { miR-192, miR-21, } \\
\text { miR-223, } \\
\text { miR-26a, miR-27a } \\
\text { and miR-801 }\end{array}$ & $\begin{array}{l}\text { Hepatitis } \mathrm{B} \quad \text { Virus-Related } \\
\mathrm{HCC} \\
\quad(\mathrm{n} \approx 800)\end{array}$ & $\begin{array}{l}\text { Clearly differentiate between health Hepatitis B } \\
\text { Virus and Hepatocellular carcinoma }\end{array}$ & 109 \\
\hline miR-122 & $\begin{array}{l}\text { Hepatitis C Virus } \\
(\mathrm{n}=68)\end{array}$ & $\begin{array}{l}\text { Correlate the necro-inflammation with chronic } \\
\text { hepatitis } \quad \mathrm{C} \text { virus infection }\end{array}$ & 110 \\
\hline $\begin{array}{l}\mathrm{miR}-122, \mathrm{miR} \\
-148 \mathrm{a}, \mathrm{miR}-194 \\
\end{array}$ & Liver transplant & $\begin{array}{l}\text { Show the rejection and hepatic injury after liver } \\
\text { transplantation }\end{array}$ & 111 \\
\hline $\begin{array}{l}\operatorname{miR}-571, \\
\operatorname{miR}-652\end{array}$ & $\begin{array}{l}\text { Hepatitis } \mathrm{C} \text { induced liver } \\
\text { cirrhosis or Alcoholic patients }\end{array}$ & $\begin{array}{l}\text { reflect their putative roles in } \\
\text { the mediation of fibrogenic and inflammatory pro- } \\
\text { cesses in distinct cellular compartments involved in } \\
\text { the pathogenesis of liver cirrhosis }\end{array}$ & 106 \\
\hline miR-21 & $\begin{array}{l}\text { HCC, chronic hepatitis }(n= \\
\text { 166) }\end{array}$ & A promising biomarker for $\mathrm{HCC}$ & 112 \\
\hline $\begin{array}{l}\text { miR-106b , miR } \\
181 \mathrm{~b}\end{array}$ & Hepatitis B Virus $\quad(n=62)$ & Show high diagnostic accuracy for liver cirrhosis & 90 \\
\hline $\begin{array}{l}\mathrm{miR}-197-3 \mathrm{p}, \mathrm{mi} \\
\mathrm{R}-505-3 \mathrm{p}\end{array}$ & $\begin{array}{l}\text { Primary } \begin{array}{r}\text { biliary } \\
\text { cirrho- } \\
\text { sis }(n=10), \text { Hepatitis B Virus } \\
(n=5), \text { Hepatitis C Virus }(n=5)\end{array} \\
\end{array}$ & $\begin{array}{l}\text { Down-regulation of both these markers serve as } \\
\text { clinical biomarker of primary biliary cirrhosis }\end{array}$ & 113 \\
\hline miR-483-5p & $\mathrm{HCC}(\mathrm{n}=69)$ & Highly expressed in HCC tumor tissues & 114 \\
\hline $\begin{array}{l}\text { miR-20a and } \\
\text { miR-92a }\end{array}$ & Hepatitis C Virus $(\mathrm{N}=58)$ & $\begin{array}{l}\text { Sensitive and cost-effective biomarkers for early } \\
\text { detection of HCV infection. }\end{array}$ & 115 \\
\hline miR-122 & $\begin{array}{ccc}\text { chronic } & \text { Hepatitis } & \mathrm{C} \\
\text { rus-induced fibrosis }(\mathrm{n}=164)\end{array}$ & Reflect the liver injury and inflammation & 116 \\
\hline 16 miRNA panel & $\begin{array}{l}\text { Hepatitis B Virus in chil- } \\
\text { dren(n=60) }\end{array}$ & Reflect Hepatitis B Virus in children & 117 \\
\hline $\begin{array}{r}\text { microRNA-122, } \\
\text { microRNA-22 }\end{array}$ & $\begin{array}{c}\begin{array}{c}\text { Hepatitis } \\
(\mathrm{n}=198)\end{array} \\
\end{array}$ & $\begin{array}{l}\text { miR-122 and miR-22 levels were elevatedin acute } \\
\text { or chronic HBV infection }\end{array}$ & 118 \\
\hline
\end{tabular}




\begin{tabular}{|c|c|c|c|}
\hline $\begin{array}{l}\text { miR-125b-5p } \\
\text { and miR223-3p }\end{array}$ & $\begin{array}{l}\text { Hepatitis B Virus -positive } \\
\text { HCC } \\
(\mathrm{n}=66)\end{array}$ & $\begin{array}{l}\text { Novel biomarkers of HBV-positive HCC in very } \\
\text { early and chronic stage }\end{array}$ & 119 \\
\hline miR-122 & $\begin{array}{l}\text { chronic hepatitis } \mathrm{C} \text { pa- } \\
\text { tients }(\mathrm{n}=25)\end{array}$ & miR-122 reflects HCV infection & 120 \\
\hline miR-106 b & $\begin{array}{l}\text { Hepatocellular carcinoma } \\
(\mathrm{n}=104)\end{array}$ & $\begin{array}{l}\text { Independent biomarker for predicting the clinical } \\
\text { prognosis of HCC }\end{array}$ & 121 \\
\hline 52 miRNA panel & $\begin{array}{l}\text { HCV-associateddiffuse large } \\
\text { B-cell lymphoma }(\mathrm{n}=97)\end{array}$ & $\begin{array}{l}\text { Reflect HCV-associated diffuse large B-cell lym- } \\
\text { phoma }\end{array}$ & 122 \\
\hline
\end{tabular}

Table 6. Some studies show serum alteration on mi RNA in hunan liver diseases

\section{Conclusion}

Liver being a dynamic and vital organ participates actively in multi-metabolic functions of foods, chemicals, biological and xenobiotic as well as detoxification of viral and bacterial products. The present review focus on types of liver injury and damage elicit by various factors along with serum, genomics, proteomics, and metabolomics biomarkers. This review also focuses on new emerging biomarkers mi RNA appeared in different liver diseases. The various risk factors such as age, gender, alcohol, medication interaction, genetic factors and nutrition are also been outlined. All the biomarkers considered show specificity and sensitivity which is useful tool in understanding the liver injury. Furthermore the review should be helpful for researchers pursuing in field of Hepatology, hepatic disorders and Hepatoprotective drugs.

\section{Author Contribution}

The first author of the manuscript has given a frame to manuscript while work has done by corresponding author.

\section{Conflict of interest}

There is no conflict of interest with anyone.

\section{Acknowledgments}

There is no funding or sponsorship.

\section{References}

1. Njoku DB. Drug-induced hepatotoxicity: Metabolic, genetic and immunological basis. International Journal of Molecular Science 2014; 15(4):6990-7003.
2. Abboud G, Kaplowitz N. Drug-induced liver injury. Drug Safety 2007; 30:277-94.

3. Boelsterli UA, Lim PL. Mitochondrial abnormalities--A link to idiosyncratic drug hepatotoxicity. Toxicology and Applied Pharmacology 2007; 220:92-107.

4. Balkwill F, Mantovani A. Inflammation and cancer: Back to Virchow? Lancet 2001; 357:539-545.

5. Fattovich G, Stroffolini T, Zagni I, et al. Hepatocellular carcinoma in cirrhosis: Incidence and risk factors. Gastroenterology 2004; 127:35-50.

6. Ganem D, Prince AM. Hepatitis B virus infectionNatural history and clinical consequences. The New England Journal of Medicine 2004; 350:1118-1129.

7. Björnsson E, Angulo P: Non-alcoholic fatty liver disease. The Scandinavian Journal of Gastroenterology 2007; 42:1023-1030.

8. Angulo P. Nonalcoholic Fatty Liver Disease. Mexican Journal of Gastroenterology 2005; 70:52-56.

9. Farrell G C, Larter CZ. Nonalcoholic fatty liver disease: From steatosis to cirrhosis. Hepatology 2006; 43:99-112.

10. Samuel VT, Liu ZX, Qu X, et al. Mechanism of hepatic insulin resistance in non-alcoholic fatty liver disease. The Journal of Biological Chemistry 2014; 279:32345-32353

11. Hirschfield GM, Chapman RW, Karlsen TH, et al. Reviews in basic and clinical gastroenterology and hepatology. Gastroenterology 2013; 144:1357-1374.

12. Katarey D, Verma S. Drug induced liver injury. Clinical Medicine 2016; 16:104-109.

13. Saadeh S. Nonalcoholic Fatty Liver Disease and Obesity. Nutrition in Clinical Practice 2007; 22:1-10

14. Powell EE, Jonsson JR, Clouston AD. Steatosis: 
Co-factor in other liver diseases. Hepatology 2005; 42:5-13.

15. Björnsson ES, Bergmann OM, Björnsson $\mathrm{H}$, et al. Incidence, presentation, and outcomes in patients with drug-induced liver injury in the general population of Iceland. Gastroenterology 2013; 144:1419-1425.

16. Lucena MI, Andrade RJ, Kaplowitz N, et al. Phenotypic characterization of idiosyncratic drug-induced liver injury: The influence of age and sex. Hepatology 2009; 49:2001-2009.

17. Fernandez-Liz E, Modamio P, Catalan A, et al. Identifying how age and gender influence prescription drug use in a primary healthcare environment in Catalonia, Spain. The British Journal of Clinical Pharmacology 2008; 65:407-417.

18. Devarbhavi H, Dierkhising R, Kremers WK. Anti-tuberculosis therapy drug-induced liver injury and acute liver failure. Hepatology 2010; 52:798-799.

19. Michikawa T, Inoue M, Sawada N, et al. Development of a prediction model for 10-year risk of hepatocellular carcinoma in middle-aged Japanese: The Japan Public Health Center-based Prospective Study Cohort II. Preventive Medicine 2012; 55:137-143.

20. Turati F, Galeone C, Rota M, et al. Alcohol and liver cancer: A systematic review and meta-analysis of prospective studies. The Annals of Oncology 2014; 25:1526-1535.

21. Thomson CA, Wertheim BC, Hingle M et al. Alcohol consumption and body weight change in post menopausal women: Results from the Women's Health Initiative. International Journal of Obesity (London) 2012; 36:1158-1164.

22. Chamorro JG, Castagnino JP, Musella RM, et al. Sex, ethnicity, and slow acetylator profile are the major causes of hepatotoxicity induced by antituberculosis drugs. The European Journal of Gastroenterology \& Hepatology 2013; 28:323-328.

23. FDA: Guidance for Industry Drug Interaction Studies - Study Design, Data Analysis, Implications for Dosing, and Labeling. Recommendationshttp://www.fda.gov/Drugs/GuidanceComplianceR egulatoryInformation/Guidances/default.htm.
24. Zaccara G, Perucca E. Interactions between antiepileptic drugs, and between antiepileptic drugs and other drugs. Epileptic Disorder 2014; 16:409-31.

25. Holecek M. Ammonia and amino acid profiles in liver cirrhosis: Effects of variables leading to hepatic encephalopathy Nutrition. 2015; 31:14-20.

26. Singla R, Sharma SK, Mohan A, et al. Evaluation of risk factors for antituberculosis treatment induced hepatotoxicity. The Indian Journal of Medical Research 2010; 132:81-86.

27. Neafsey P, Ginsberg G, Hattis D, et al. Genetic polymorphism in CYP2E1: Population distribution of CYP2E1activity. Journal of Toxicology and Environmental Health, Part B 2009; 12:362-388.

28. Vuilleumier $\mathrm{N}$, Rossier MF, Chiappe A, et al. CYP2E1genotype and isoniazid-induced hepatotoxicity in patients treated for latent tuberculosis. The European Journal of Clinical Pharmacology 2006; 62:423-429.

29. Chalasani N, Fontana RJ, Bonkovsky HL, et al. Causes, clinical features, and outcomes from a prospective study of drug-induced liver injury in the United States. Gastroenterology 2008; 135:1924-1934.

30. Lammert C, Einarsson S, Saha C, et al. Relationship between daily dose of oral medications and idiosyncratic drug-induced liver injury: Search for signals. Hepatology 2008; 47:2003-2009.

31. Pari L, Karthikesan K. Protective role of caffeic acid against alcohol-induced biochemical changes in rats. Fundamental \& Clinical Pharmacology 2007; 21:355-361.

32. Testino G, Leone S, Borro P. Alcohol and hepatocellular carcinoma: A review and a point of view. World Journal of Gastroenterology 2014; 20:15943-15954.

33. Sheron N, Hawkey C, Gilmore I. Projections of alcohol deaths--A wake-up call. Lancet 2011; 377:1297-1299.

34. Saravanan S, Pandikumar P, Pazhanivel N, et al. Hepatoprotective role of abelmoschus esculentus (Linn.) moench, on carbon tetrachloride-induced liver injury. Toxicology Mechanisms and Meth- 
ods 2013; 23:528-536.

35. Manibusan MK, Odin M, Eastmond DA. Postulated carbon tetrachloride mode of action: A review. The Journal of Environmental Science and Health, Part C: Environmental Carcinogenesis and Ecotoxicology Reviews 2007; 25: 185-209.

36. Feng $\mathrm{Y}$, Wang $\mathrm{N}$, Ye X, et al. Hepatoprotective effect and its possible mechanism of coptidis rhizoma aqueous extract on carbon tetrachloride-induced chronic liver hepatotoxicity in rats.The Journal of Ethno pharmacology 2011; 138:683-690.

37. Debnath S, Ghosh S, Hazra B. Inhibitory effect of nymphea pubescens wild flower extract on carrageenan-induced inflammation and CCl4-induced hepatotoxicity in rats. Food and Chemical Toxicology 2013; 59:485-491.

38. Bissoli F. Nimesulide-induced hepatotoxicity and fatal hepatic failure 2008; 49: 436-437.

39. Hussaini SH, Farrington EA. Idiosyncratic drug-induced liver injury: An update on the 2007 overview. Expert Opinion on Drug Safety 2014; 13:67-81.

40. Unzueta A, Vargas HE. Nonsteroidal anti-inflammatory drug-induced hepatoxicity. Clinical liver Disease 2013; 17:643-56.

41. Cover C, Liu J, Farhood A, et al. Pathophysiological role of the acute inflammatory response during acetaminophen hepatotoxicity. Toxicology and Applied Pharmacology 2006; 216:98-107.

42. Graham GG, Scott KF, Day RO. Tolerability of paracetamol. Drug Safety 2005; 28:227-40.

43. Lee TY, Chang HH, Wen CK, et al. Modulation of thioacetamide induced hepatic inflammation, angiogenesis and fibrosis by andrographolide in mice. Journal of Ethnopharmacology 2014; 158:423-430.

44. Jang YO, Kim MY, Cho MY, et al. Effect of bone marrow-derived mesenchymal stem cells on hepatic fibrosis in a thioacetamide-induced cirrhotic rat mode. BMC Gastroenterology 2014; 14:1-12.

45. Hajovsky H, Hu G, Koen Y, et al. Metabolism and toxicity of thioacetamide and thioacetamide S-oxide in rathepatocytes.Chemical Research in Toxicology 2012; 25:1955-1963.

46. Petit E, Langouet $\mathrm{S}$, Akhdar $\mathrm{H}$, et al. Differential toxic effects of azathioprine, 6-mercaptopurine and 6-thioguanine on human hepatocytes. Toxicology In Vitro 2008; 22: 632-642.

47. El-Beshbishy HA, Tork OM, El-Bab MF, et al. Antioxidant and antiapoptotic effects of green tea polyphenols against azathioprine-induced liver injury in rats. Pathophysiology 2011; 18:125-135.

48. Suarez J, Ranguelova K, Jarzecki AA, et al. An oxyferrousheme/protein-based radical intermediate is catalytic ally competent in the catalasereaction of Mycobacterium tuberculosis catalase-peroxidase. The Journal of Biological Chemistry 2009; 284:7017-7029.

49. Saad E I, El-Gowilly SM, Sherhaa MO, et al. Role of oxidative stress and nitric oxide in the protective effects of alpha-lipoic acid and aminoguanidine against isoniazid-rifampicin-induced hepatotoxicity in rats. Food and Chemical Toxicology 2010; 48:1869-1875.

50. Huang YS, Chern HD, Su WJ, et al. Cytochrome P450 2E1genotype and the susceptibility to antituberculosis drug-induced hepatitis. Hepatology $2003 ; 37: 924-930$.

51. Strautnieks SS, Bull LN, Knisely AS, et al. A gene encoding a liver-specific $\mathrm{ABC}$ transporter is mutated in progressive familial intrahepatic cholestasis. Nature Genetics 1998; 20:233-238.

52. Faubion WA, Gores GJ. Death receptors in liver biology and pathobiology Hepatology 1999; 29:1-4.

53. Faubion WA, Guicciardi ME, Miyoshi $\mathrm{H}$, et al. Toxic bile salts induce rodent hepatocyte apoptosis via directs activation of Fas. The Journal of Clinical Investigation 1999; 103:137-145.

54. Miyoshi H, Rust C, Roberts PJ et al. Hepatocyte apoptosis after bile duct ligation in the mouse involves Fas. Gastroenterology 1999; 117:669-677.

55. Amacher DE. Toxicologist's guide to biomarkers 
of hepatic response. Human \& amp; Experimental Toxicology 2002; 21:253-262.

56. Ozer J, Ratner M, Shaw M, et al. The current state of serum biomarkers of hepatotoxicity. Toxicology 2008; 245:194-205.

57. Shi L, Wu LL, Yang JR, et al. Serum peroxiredoxin3 is a useful biomarker for early diagnosis and assessemnt of prognosis of hepatocellular carcinoma in Chinese patients. The Asian Pacific Journal of Cancer Prevention 2014; 15:2979-2986.

58. Kim HC, Nam CM, Jee SH, et al. Normal serum aminotransferase concentration and risk of mortality from liver disease: Prospective cohort study. BMJ 2004; 328:1-6.

59. Zhao P, Liu WW, Li JF, et al. Predictors of liver failure in primary biliary cirrhosis. Upsala Journal of Medical Sciences 2015; 28:1-5.

60. Wintrobe MM, Greer JP. Wintrobe's Clinical hematology. Lippincott Williams and Wilkins, 12th edition 2009.

61. Targher G. Elevated serum gamma-glutamyltransferase activity is associated with increased risk of mortality, incident type 2 diabetes, cardiovascular events, chronic kidney disease and cancer - a narrative review. Clinical Chemistry and Laboratory Medicine 2010; 48:147-157.

62. Geuken E, Visser D, Kuipers F, et al. Rapid increase of bile salt secretion is associated with bile duct injury after human liver transplantation. Journal of Hepatology 2004; 41:1017-1025.

63. Zollner G, Marschall HU, Wagner M, et al. Role of nuclear receptors in the adaptive response to bile acids and cholestasis: Pathogenetic and therapeutic considerations. Molecular Pharmaceutics 2006; 3:231-251.

64. Ji C, Wu H, Wei L, et al. Proteomic and metabolomic analysis reveal gender-specific responses of mussel Mytilus galloprovincialis to 2,2',4,4'-tetrabromodiphenyl ether (BDE 47). Aquatic Toxicology 2013; 15:449-457.

65. Mendrick DL, Schnackenberg L. Genomic and metabolomic advances in the identification of disease and adverse event biomarkers. Bi- omarkers in Medicine 2009; 3:605-615.

66. Fitzpatrick E, Dhawan A. Noninvasive biomarkers in non-alcoholic fatty liver disease: Current status and a glimpse of the future. World Journal of Gastroenterology 2014; 20:10851-10863.

67. Gupta N, Benhamida J, Bhargava Vang J, et al. Comparative proteogenomics: Combining mass spectrometry and comparative genomics to analyze multiple genomes. Genome Research 2008; 18:1133-1142.

68. Coen M. Metabolic phenotyping applied to pre-clinical and clinical studies of acetaminophen metabolism and hepatotoxicity. Drug Metabolism Reviews 2015; 23:1-16.

69. Filipowicz W, Bhattacharyya SN, Sonenberg N. Mechanisms of post-transcriptional regulation by microRNAs: Are the answers in sight? Nature Reviews Genetics 2008; 9:102-114.

70. Gori M, Arciello M, Balsano C. MicroRNAs in nonalcoholic fatty liver disease: Novel biomarkers and prognostic tools during the transition from steatosis to hepatocarcinoma. BioMed Research International 2014; 1-14.

71. Zhang Y, Jia Y, Zheng R, et al. Plasma microRNA-122 as a biomarker for viral-, alcohol-, and chemical-related hepatic diseases. Clinical Chemistry 2010; 56:1830-1838.

72. Baraniskin A, Kuhnhenn J, Schlegel U, et al. Identification of microRNAs in the cerebrospinal fluid as marker for primary diffuse large B-cell lymphoma of the central nervous system. Blood 2011; 117:3140-3146.

73. Cermelli S, Ruggieri A, Marrero JA, et al. Circulating microRNAs in patients with chronic hepatitis $\mathrm{C}$ and non-alcoholic fatty liver disease. PLoS One 2011; 6:1-8.

74. Roderburg C, Mollnow T, Bongaerts B, et al. Micro-RNA profiling in human serum reveals compartment-specific roles of miR-571 and miR-652 in liver cirrhosis. PLoS One 2012; 7:1-11.

75. Tan Y, Ge G, Pan T, et al. A pilot study of serum microRNAs panel as potential biomarkers for diagnosis of nonalcoholic fatty liver disease. 
PLoS One 2014; 9:1-12.

76. Bosetti C, Levi F, Lucchini F et al. Worldwide mortality from cirrhosis: An update to 2002. Journal of Hepatology 2007; 46:827-839.

77. Mokdad AA, Lopez AD, Shahraz S, et al. Liver cirrhosis mortality in 187countries between 1980 and 2010: a systematic analysis. BMC Medicine 2014; 18:1-24.

78. Vitins AP, Kienhuis AS, Speksnijder EN, et al. Mechanisms of amiodarone and valproic acid induced liver steatosis in mouse in vivo act as a template for other hepatotoxicity models. Archives of Toxicology 2014; 88:1573-1588.

79. Slim R, Fathallah N, Aounallah A, et al. Paracetamol-induced Stevens Johnson syndrome and cholestatic hepatitis.Current drug safety 2015; 10:187-189.

80. Xie Y, Wang G, Wang H. Cytochrome P450 dysregulations in thioacetamide-induced liver cirrhosis in rats and the counteracting effects of hepatoprotective agents. Drug Metabolism and Disposition 2012; 40:796-802.

81. Dawwas MF, Aithal GP. End-stage methotrexate-related liver disease is rare and associated with features of the metabolic syndrome. Alimentary Pharmacology \&amp; Therapeutics 2014; 40:938-948.

82. Yuan L, Kaplowitz N. Mechanisms of drug-induced liver injury. Clinical Liver Disease $2013 ; 17: 507-518$.

83. Al-Halawani M Z, Thawabi M, Asslo F, et al. Losartan-induced Ischemic Hepatocellular Hepatotoxicity: A Case Report and Literature Review. Journal of Family Medicine and Prime Care 2014; 3:272-274.

84. Poli G, Biasi F, Leonarduzzi G. 4-Hydroxynonenal-proteinadducts: A reliable biomarker of lipid oxidation in liver diseases. Molecular Aspects of Medicine 2008; 29:67-71.

85. Poynard T, Ratziu V, Naveau S, et al. The diagnostic value of biomarkers (SteatoTest) for the prediction of liver steatosis. See comment in PubMed Commons belowComp. Hepatol 2005; 23:4-10.

86. Wang X, Zhang A, Han Y, et al. Urine metabo- lomics analysis for biomarker discovery and detection of jaundice syndrome in patients with liver disease. Mol. Cell Proteomics 2012; 11:370-380.

87. Wang J, Chen R, Tang S, et al. Interleukin-4 and interleukin-10 polymorphisms and antituberculosis drug-induced hepatotoxicity in Chinese population. Journal of Clinical Pharm Ther 2014; 1-6.

88. El-Meghawry, El-Kenawy A, Osman HE, et al. The effect of vitamin $\mathrm{C}$ administration on monosodium glutamate induced liver injury. An experimental study. Exp Toxicol Pathol 2013; 65:513-521.

89. Yang SL, Fang X, Huang ZZ, et al. Can serum glypican-3 be a biomarker for effective diagnosis of hepatocellular carcinoma? A meta-analysis of the literature. Dis. Markers 2014; 1-11.

90. Chen R, Wang J, Tang S, et al. Association of polymorphisms in drug transporter genes (SLCO1B1 and SLC10A1) and anti-tuberculosis drug-induced hepatotoxicity in a Chinese cohort. Tuberculosis (Edinb). 2014; 1-7.

91. Chen X, Ba Y, Ma L, et al. Characterization of microRNAs in serum: a novel class of biomarkers for diagnosis of cancer and other diseases. Cell Research 2008; 18:997-1006.

92. Wang Y, Lee AT, Ma JZ, et al. Profiling microRNAexpression in hepatocellular carcinoma reveals microRNA-224up-regulation and apoptosis inhibitor-5 as a microRNA-224-specifictarget. J. Biol. Chem 2008; 283:13205-13215.

93. Yang Y, Fan YC, Gao S, et al. Methylated cysteine dioxygenase-1 gene promoter in the serum is a potential biomarker for hepatitis B virus-related hepatocellular carcinoma. Tohoku J. Exp. Med. 2014; 232:187-194.

94. Manosuthi W, Sukasem C, Lueangniyomkul A, et al. CYP2B6 haplotype and biological factors responsible for hepatotoxicity in HIV-infected patients receiving efavirenz-based antiretroviral therapy. International Journal of Antimicrobial Agents 2014; 43:292-296.

95. Chen YJ, Zhu JM, Wu H, et al. Circulating mi- 
croRNAs as a Fingerprint for Liver Cirrhosis. PLoS One 2013; 8:1-9.

96. Mishra S, Daschakraborty S, Shukla P, et al. $\mathrm{N}$-acetyltransferase and cytochrome P450 2E1 gene polymorphisms and susceptibility to antituberculosis drug hepatotoxicity in an Indian population. Natl. Med. J. India 2013; 26:260-265.

97. Li L M, Chen L, Deng GH, et al. SLCO1B1 15 haplotype is associated with rifampin-induced liver injury. Molecular Medicine Rep 2012; 6:75-82.

98. Targher G. Relationship between high-sensitivity C-reactive protein levels and liver histology in subjects with non-alcoholic fatty liver disease. Journal of Hepatology 2006; 45:879-881.

99. Kumar R, Prakash S, Chhabra S, et al. Association of pro-inflammatory cytokines, adipokines \&amp; oxidative stress with insulin resistance \& amp; non-alcoholic fatty liver disease. Indian Journal of Medicinal Research 2012; 136:229-236.

100. Wang Y, Lee A T, Ma JZ, et al. Profiling microRNA expression in hepatocellular carcinoma reveals microRNA-224up-regulation and apoptosis inhibitor-5 as a microRNA-224-specifictarget. Journal of Biological Chemistry 2008; 283:13205-13215.

101. Yamamoto Y, Kosaka N, Tanaka M et al. MicroRNA-500 as a potential diagnostic marker for hepatocellular carcinoma. Biomarkers 2009; 14:529-538.

102. Huang $\mathrm{XH}$, Wang $\mathrm{Q}$, Chen JS, et al. Bead-basedmicroarrayanalysis of microRNA expression in hepatocellular carcinoma: miR-338 is down regulated. Hepatol. Res. 2009; 39:786-794.

103. Li L M, Hu ZB, Zhou ZX, et al. Serum microRNA profiles serve as novel biomarkers for HBV infection and diagnosis of HBV-positive hepatocarcinoma. Cancer Research 2010; 70:9798-9807.

104. Gui J, Tian Y, Wen X, et al. Serum microRNA characterization identifies miR-885-5p as a potential marker for detecting liver pathologies.
Clinical Science (Lond). 2011; 120:183-193.

105. Qi P, Cheng SQ, Wang H, et al. Serum microRNAs as biomarkers for hepatocellular carcinoma in Chinese patients with chronic hepatitis B virus infection. PLoS One 2011; 6:1-8.

106. Roderburg $\mathrm{C}$, Luedde $\mathrm{M}$, Vargas $\mathrm{CD}$, et al. MiR-133a mediates TGF- $\beta$-dependent derepression of collagen synthesis in hepatic stellate cells during liver fibrosis. Journal of Hepatology 2013; 58:736-742.

107. Starkey LPJ, Dear J, Platt V, et al. Circulating microRNAs as potential markers of human drug-induced liver injury. Hepatology 2011; 54:1767-1776.

108. $\mathrm{Xu} \mathrm{J}, \mathrm{Wu} \mathrm{C}$, Che $\mathrm{X}$, et al. Circulating microRNAs, miR-21, miR-122, and miR-223, in patients with hepatocellular carcinoma or chronic hepatitis. 2011; 50:136-142.

109. Zhao P, Liu WW, Li JF, et al. Predictors of liver failure in primary biliary cirrhosis. Upsala Journal of Medical Sciences 2015; 28:1-5.

110. Bihrer V, Friedrich-Rust M, Kronenberger B, et al. Serum miR-122 as a biomarker of necro inflammation in patients with chronic hepatitis $\mathrm{C}$ virus infection. American Journal of Gastroenterology 2011; 106:1663-1669.

111. Farid WR, Pan Q, van der Meer AJ, et al. Hepatocyte-derived microRNAs as serum biomarkers of hepatic injury and rejection after liver transplantation. Liver Transplant 2012; 18:290-297.

112. Tomimaru Y, Eguchi H, Nagano H, et al. Circulating microRNA-21 as a novel biomarker for hepatocellular carcinoma. Journal of Hepatology 2012; 56:167-175.

113. Ninomiya M, Kondo Y, Funayama R, et al. Distinct microRNAs expression profile in primary biliary cirrhosis and evaluation of miR 505-3p and miR197-3p as novel biomarkers. PLoS One. 2013; 8:1-11.

114. Shen J, Wang A, Wang Q, et al. Exploration of genome-wide circulating microRNA in hepatocellular carcinoma: MiR-483-5p as a potential biomarker. Cancer Epidemiology Biomarkers Preview 2013; 22:2364-2373. 
115. Shrivastava $\mathrm{S}$, Petrone $\mathrm{J}$, Steele $\mathrm{R}$, et al. Up-regulation of circulating miR-20a is correlated with hepatitis $\mathrm{C}$ virus-mediated liver disease progression. Hepatology 2013; 58:863-871.

116. Trebicka J, Anadol E, Elfimova N, et al. Hepatic and serum levels of miR-122 after chronic $\mathrm{HCV}$-induced fibrosis. Journal of Hepatology 2013; 58:234-239.

117. Winther TN, Heiberg IL, Bang-Berthelsen $\mathrm{CH}$, et al. Hepatitis B surface antigen quantity positively correlates with plasma levels of microRNAs differentially expressed in immunological phases of chronic hepatitis B in children. PLos One 2013; 8:1-13.

118. Arataki K, Hayes CN, Akamatsu S, et al. Circulating microRNA-22 correlates with microRNA-122 and represents viral replication and liver injury in patients with chronic hepatitis. British Journal of Medicine and Virology
2013; 85:789-798.

119. Giray BG, Emekdas G, Tezcan S, et al. Profiles of serum microRNAs; miR-125b-5p and miR223-3p serve as novel biomarkers for HBV-positive hepatocellular carcinoma. Molecular Biology Report 2014; 41:4513-4519.

120. Kumar S, Chawla YK, Ghosh S, et al. Severity of hepatitis $\mathrm{C}$ virus (genotype-3) infection positively correlates with circulating microRNA-122 in patients sera. Dis. Markers 2014; 1-6.

121. Li BK, Huang PZ, Qiu JL, et al. Upregulation of microRNA-106b is associated with poor prognosis in hepatocellular carcinoma. Diagn Pathology 2014; 9.

122. Augello C, Gianelli U, Savi F, et al. MicroRNA as potential biomarker in HCV-associated diffuse large B-cell lymphoma. Journal of Clinical Pathology 2014; 67:697-701. 